\title{
Prognostic significance of body mass index and diabetes in patients with malignant glioma
}

\section{Malign gliom hastalarında vücut kitle indeksi ve diyabetin prognostik önemi}

\author{
Berrin Benli Yavuz ${ }^{*}$ (D), Gul Kanyilmaz ${ }^{1}$ (D), Meryem Aktan ${ }^{1}$ \\ ${ }^{1}$ Department of Radiation Oncology, Meram Medical School, Necmettin Erbakan University, Konya, Turkey \\ * Corresponding author: Berrin Benli Yavuz E-mail: berrinyavuz77@gmail.com ORCID: 0000-0001-7816-4687 \\ Received: 16 April 2020 Accepted: 22 May 2020
}

\begin{abstract}
Aim: We aimed to determine whether there is a relationship between body mass index (BMI) and diabetes (DM) before treatment and survival with this study.

Material and Methods: The results of patients who received radiotherapy between 2010 - 2018 were evaluated with this retrospective study. BMI was categorized into 3 groups: normal (18.5-24.9 kg/m2), overweight (25-29.9 kg/m2), obese ( $\geq 30$ $\mathrm{kg} / \mathrm{m} 2$ ). Presence of diabetes was evaluated by considering oral antidiabetic use and file information before treatment. Patient, treatment and tumor characteristics were evaluated with descriptive statistics. Kaplan-Meirer, log-rank and coxregression analyzes were performed. $\mathrm{P}<0.05$ was considered statistically significant.

Results: The results of 174 cases were evaluated. Diabetes was present in 22 patients (12.6\%). In univariate analyzes, being over the age of 65 ( $p<0.001$ ), Karnofsky performance score (KPS) below 80 ( $p<0.001$ ), diabetes ( $p=0.017$ ), having grad 4 pathology ( $p<0.001$ ), performing subtotal excision / biopsy $(p<0.001)$, hypofractioned / whole brain radiotherapy ( $p$ $<0.001)$, and not receiving adjuvant chemotherapy (CT) ( $<<0.001$ ) had a negative effect on overall survival (OS). In multivariate analyzes, being over 65 years old, having grad 4 pathology, performing subtotal excision / biopsy and not taking adjuvant CT were found to be effective on OS. Median overall survival in diabetics was 9.65 months and 17.74 months in non-diabetics $(p=0.017)$. No statistically significant relationship was found between BMI and OS.
\end{abstract}

Conclusion: Pre-existing diabetes in malignant glioma patients is a risk factor for poor outcomes. It is important to control diabetes and related conditions.

Keywords: malign glioma, diabetes, body mass index, prognosis 


\section{ÖZ}

Amaç: Bu çalışma ile tedavi öncesi vücut kitle indeksi (VKI) ve diyabet ile sağ kalım arasında bir ilişki olup olmadığını belirlemeyi amaçladık.

Gereç ve Yöntemler: Bu retrospektif çalışma ile 2010-2018 tarihleri arasında radyoterapi (RT) uygulanmış hastaların sonuçları değerlendirildi. VKI, 3 gruba kategorize edildi: normal (18,5-24,9 kg/m²), aşırı kilolu $\left(25-29,9 \mathrm{~kg} / \mathrm{m}^{2}\right)$, obez $(\geq 30$ $\mathrm{kg} / \mathrm{m}^{2}$ ). Diyabet varlığı, hastaların tedavi öncesi oral antidiyabetik kulanımı ve dosya bilgileri göz önüne alınarak değerlendirildi. Hasta, tedavi ve tümör karakteristikleri tanımlayıcı istatistikler ile değerlendirildi. Kaplan-Meirer, log-rank ve çoklu analizlerde cox-regresyon analizleri yapıldı. $\mathrm{P}<0,05$ istatistiki anlamlı olarak kabul edildi.

Bulgular: 174 olgunun sonuçları değerlendirildi. Diyabet hastaların 22'sinde $(\% 12,6)$ mevcuttu. Tek değişkenli analizlerde, 65 yaş üstünde olmak ( $p<0,001$ ), Karnofsky performans skorunun (KPS) 80'in altında olması ( $<<0,001$ ), diyabet olması $(p=0,017)$, grad 4 patolojiye sahip olmak $(p<0,001)$, subtotal eksizyon/biopsi yapılması $(p<0,001)$, hipofraksiyone/tüm beyin radyoterapisi uygulanması ( $p<0,001)$ ve adjuvan kemoterapi $(K T)$ almamak $(p<0,001)$ genel sağ kalım üzerinde olumsuz etkili idi. Çok değişkenli analizlerde ise, 65 yaş üstü olmak, grad 4 patolojiye sahip olmak, subtotal eksizyon/biopsi yapılması ve adjuvan KT almamak genel sağ kalım (GS) üzerine etkili olarak bulundu. Diyabetiklerde medyan genel sağkalım 9,65 ay iken diyabetik olmayanlarda 17,74 ay idi $(p=0,017)$. VKI ile GS arasında istatistiki anlamlı bir ilişki gösterilemedi.

Sonuç: Önceden var olan diyabet kötü sonuçlar açısından bir risk faktörüdür. Diyabet ve ilişkili durumların kontrol altında olması önemlidir.

Anahtar kelimeler: malign glioma, diyabet, vücut kitle indeksi, prognoz

\section{INTRODUCTION}

Malignant gliomas account for about half of all brain tumors in adults [1]. The World Health Organization (WHO) classifies grad 3 (anaplastic gliomas) and grad 4 (glioblastoma) gliomas as malign gliomas [1]. Currently the standard treatment applied to high grade glioma involves a maximally-safe resection, concurrent radiotherapy (RT) and temozolamide treatment followed by adjuvant temozolamide [2]. Despite all treatments, survival is very low in malignant gliomas. 5 -year survival is $18 \%$ for WHO grad 3 tumors and $<5 \%$ for glioblastomas (GBM) [3]. In addition to known bad prognostic factors such as age, 0-6 methylguanine DNA methyltransferase (MGMT) status, Karnofsky performance score (KPS), it is important to identify prognostic factors before treatment [4].

Obesity and diabetes (DM) are among the most important health problems in the world [5]. Cancer incidence is expected to increase due to increased risk factors such as obesity, DM and lifestyle [6,7]. While $9.3 \%$ of the global adult population is diabetes in the world [8], this rate was found to be $9-15.7 \%$ in studies conducted with glioma patients $[3,9,10]$. World health organization defines obesity as body mass index $(\mathrm{BMI}) \geq 30 \mathrm{~kg} / \mathrm{m}^{2}$ and overweight as $\mathrm{BMI} \geq 25 \mathrm{~kg} /$ $\mathrm{m}^{2}$ [5]. The prevalence of obesity in the Turkey was reported to be $28.5 \%$ [11]. In studies on gliomas, the frequency of obesity was found between 20-30 [3,9,12]. Increased BMI has been associated with various types of cancer: colorectal cancers, breast, endometrium, ovarian, kidney, pancreas, esophageal cancers $[13,14]$. It was stated that DM and high BMI contributed to $5.7 \%$ of all incidental cancer cases in 2012 in a study conducted in 2018 [10]. There is evidence that DM is associated with endometrium, bladder, pancreas, liver, colorectal and breast cancer $[3,9,15]$. The underlying cause of the relationship between BMI, DM and cancer is hyperglycemia, hyperinsulinemia, chronic inflammation, and irregularity in sex hormone activity [10]. However, the relationship between malignant gliomas and high $\mathrm{BMI}$ and DM is contradictory in studies. Therefore, with this study, we aimed to determine the relationship between malignant gliomas and DM, high BMI.

\section{MATERIAL AND METHODS}

With this study, the results of 174 patients who received radiotherapy in our clinic between January 2010 and December 2018 were retrospectively analyzed. The study included grade 3-4 glioma patients according to WHO criteria, over the age of 18, whose diagnosis was confirmed by histopathologically, weight, height and DM story can be reached. Type 1 diabetes patients were not excluded from the study. Ethics committee approval was obtained before starting the study. Due to the nature of the study, informed 
consent forms were not obtained from the patients. Patient data and treatment characteristics were obtained from medical records and hospital system.

Body mass index was calculated according to the $\mathrm{kg} / \mathrm{m} 2$ formula, considering weight and height measurements before treatment. It was categorized into 3 groups: normal weight (18.5-24.9 kg / $\left.\mathrm{m}^{2}\right)$, overweight (25-29.9 kg / $\left.\mathrm{m}^{2}\right)$, obese $\left(\geq 30 \mathrm{~kg} / \mathrm{m}^{2}\right)$.

The presence of diabetes was defined by considering disease history, antidiabetic use, blood glucose levels at least 6 months before the operation.

Groups were categorized as gross total excision (GTR) and subtotal excision/biopsy considering the resection width operation notes and Magnetic Resonance Imaging (MR) images taken after surgery.

\section{Radiotherapy}

All patients were treated with 3D conformal radiotherapy. Conventional radiotherapy was considered as a 1.8-2 Gy fraction dose and $50 \mathrm{~Gy}$ and above dose. 30-42.5 Gy RT was applied in 10-16 fractions in hypofraction and whole brain radiotherapy. RT was started within 5-6 week after the operation. MRI was performed in each patient before RT. CT simulation was performed in supine position for planning purposes. By fixing with a thermoplastic mask, a tomography of 3-5 mm section thickness was taken. Computed tomography (CT) images were fused with preop and postop MR images. Gross tumor volume (GTV) was defined as the volume and operation bed enhanced by MR image. This volume was created by giving the clinical target volume (CTV) with a margin of $1.5-2 \mathrm{~cm}$ and the planned tumor volume (PTV) with a margin of $0.5 \mathrm{~cm}$ to CTV. All brain RT was applied with 3D conformal radiotherapy, hypofractionated or conventional treatments were applied with intensity-adjusted RT (IMRT). All patients were treated with eclipse planning system.

\section{Chemotherapy}

Simultaneously, $75 \mathrm{mg} / \mathrm{m}^{2} /$ day temozolomide treatment was applied 7 days a week. After RT, adjuvant chemotherapy (CT) was administered as $150-200 \mathrm{mg} / \mathrm{m}^{2} /$ day, every 5 days for 5 days. Temozolomide was applied in 6-12 cycles.

\section{Follow-up}

During the treatment, a complete blood count, biochemistry tests and a physical examination were performed once a week. Potential side effects were evaluated. After RT, he/she was followed up with a physical examination and MR every 3 months.

\section{Endpoint}

The primary endpoint of the study was overall survival (OS). The second endpoint was to determine the effect of DM and BMI on OS.

\section{Statistical Analysis}

Descriptive statistics were applied to determine patient and treatment characteristics. Average, median, and standard deviations were calculated in order. Overall survival was defined as the time from the time of diagnosis to death or final control. Progression-free survival was determined as the time from diagnosis until relapse or progression, or until death. Chi-square test was carried out to compare the categorical variables. Kaplan Meier Analysis was carried out for survival analysis. In univariate analysis, the survival curves of the subgroups were evaluated with a log-rank test. In univariate analysis, all variables with $\mathrm{p}<0.10$ were included in the multivariate analysis. Cox regression analysis was performed. $\mathrm{P}<0.05$ was considered statistically significant. Version 13.0 of Statistical Package for Social Sciences Software (SPSS Inc.; Chicago, IL, USA) was utilized in the whole statistical analysis.

\section{RESULTS}

\section{Patient and Treatment Characteristics}

The results of 174 cases were evaluated retrospectively. Median follow-up was 16.11 months. The median age was 57 (18-84). 37 (21.3\%) patients had grad 3, 137 (78.7\%) patients had grad 4 pathology. DM was present in $22(12.6 \%)$ of the cases. The median BMI was $27.14 .36 .8 \%$ of the cases were normal weight, $37.4 \%$ were overweight and $25.9 \%$ were obese. Treatment and patient characteristics are summarized in Table 1.

\section{Survival Analysis}

Median survival was 17.28 months. Overall survival for 1, 2, 5 and 10 years was $64.4 \%, 34 \%, 17.7 \%$ and $10.3 \%$, respectively (Figure 1). During the follow-up period, 138 (79.3\%) patients died. Being over 65 years of age, KPS $<80$, presence of diabetes, grad 4 pathology, subtotal excision / biopsy, hypofractionated / whole brain radiotherapy and absence of adjuvant chemotherapy (CT) had negative effects on overall survival (Table 2) in univariate analysis. Being over 65 years old, having grad 4 pathology, subtotal excision and not taking adjuvant $\mathrm{CT}$ were found to be effective on OS (Table 3) in multivariate analysis. Median overall survival in diabetics was 9.65 months, while in non-diabetics 17.74 
Table 1. Patient and treatment characteristics

\begin{tabular}{|c|c|}
\hline Characteristic & n (\%) \\
\hline \multicolumn{2}{|l|}{ Age } \\
\hline median & $57(18-84)$ \\
\hline$\geq 65$ & $53(30.5)$ \\
\hline$<65$ & $121(69.5)$ \\
\hline \multicolumn{2}{|l|}{ KPS } \\
\hline$\geq 80$ & $120(68.6)$ \\
\hline$<80$ & $54(31.4)$ \\
\hline \multicolumn{2}{|l|}{ Gender } \\
\hline Male & $118(67.8)$ \\
\hline Female & $56(32.2)$ \\
\hline \multicolumn{2}{|l|}{ Type and extent of surgery } \\
\hline GTR & $58(33.3)$ \\
\hline Subtotal/Biopsy & $116(66.7)$ \\
\hline \multicolumn{2}{|l|}{ Concurrent $\mathrm{CT}$} \\
\hline None & $6(3.4)$ \\
\hline Temozolomide & $168(96.6)$ \\
\hline \multicolumn{2}{|l|}{ RT fraction } \\
\hline Conventional & $152(87.4)$ \\
\hline Hypofractionation/whole-brain & $22(12.6)$ \\
\hline \multicolumn{2}{|l|}{ Adjuvant CT } \\
\hline None & $28(16.1)$ \\
\hline Temozolomide & $146(83.9)$ \\
\hline \multicolumn{2}{|l|}{ Diabetes } \\
\hline Nondiabetic & $152(87.4)$ \\
\hline Diabetic & $22(12.6)$ \\
\hline \multicolumn{2}{|l|}{ Body mass index $\left(\mathrm{kg} / \mathrm{m}^{2}\right)$} \\
\hline $18,5-24,9$ & $64(36.8)$ \\
\hline $25-29,9$ & $65(37.4)$ \\
\hline$\geq 30$ & $45(25.9)$ \\
\hline
\end{tabular}

KPS: Karnofsky Performance Status, GTR: Gross Total Excision, CT: Chemotherapy, RT: Radiotherapy

Table 2. Factors affecting overall survival in univariate analysis

\begin{tabular}{|c|c|c|}
\hline Variances & $\begin{array}{l}\text { Median overall } \\
\text { survival }\end{array}$ & $P$ value \\
\hline \multicolumn{3}{|l|}{ Age } \\
\hline$\geq 65$ & 12.32 & \multirow{2}{*}{$<0.001$} \\
\hline$<65$ & 20.14 & \\
\hline \multicolumn{3}{|l|}{ KPS } \\
\hline$\geq 80$ & 19.51 & \multirow[b]{2}{*}{$<0.001$} \\
\hline$<80$ & 9.65 & \\
\hline \multicolumn{3}{|l|}{ Type and extent of surgery } \\
\hline Total & 28.58 & \multirow[b]{2}{*}{$<0.001$} \\
\hline Subtotal/Biopsy & 15.60 & \\
\hline \multicolumn{3}{|l|}{ Pathology } \\
\hline Grad 3 & 33.54 & \multirow[b]{2}{*}{$<0.001$} \\
\hline Grad 4 & 15.60 & \\
\hline \multicolumn{3}{|l|}{ Adjuvant CT } \\
\hline Yes & 18.99 & \multirow[b]{2}{*}{$<0.001$} \\
\hline None & 3.77 & \\
\hline \multicolumn{3}{|l|}{ RT fraction } \\
\hline Conventional & 18.99 & \multirow[b]{2}{*}{$<0.001$} \\
\hline Hypofractionation/whole-brain & 7.81 & \\
\hline \multicolumn{3}{|l|}{ Diabetes } \\
\hline Nondiabetic & 17.74 & \multirow[b]{2}{*}{0.017} \\
\hline Diabetic & 9.65 & \\
\hline \multicolumn{3}{|l|}{ Body mass index $\left(\mathrm{kg} / \mathrm{m}^{2}\right)$} \\
\hline$<30$ & 18.89 & \\
\hline$\geq 30$ & 13.47 & 0.095 \\
\hline
\end{tabular}

KPS: Karnofsky Performance Status, CT: Chemotherapy, RT: Radiotherapy

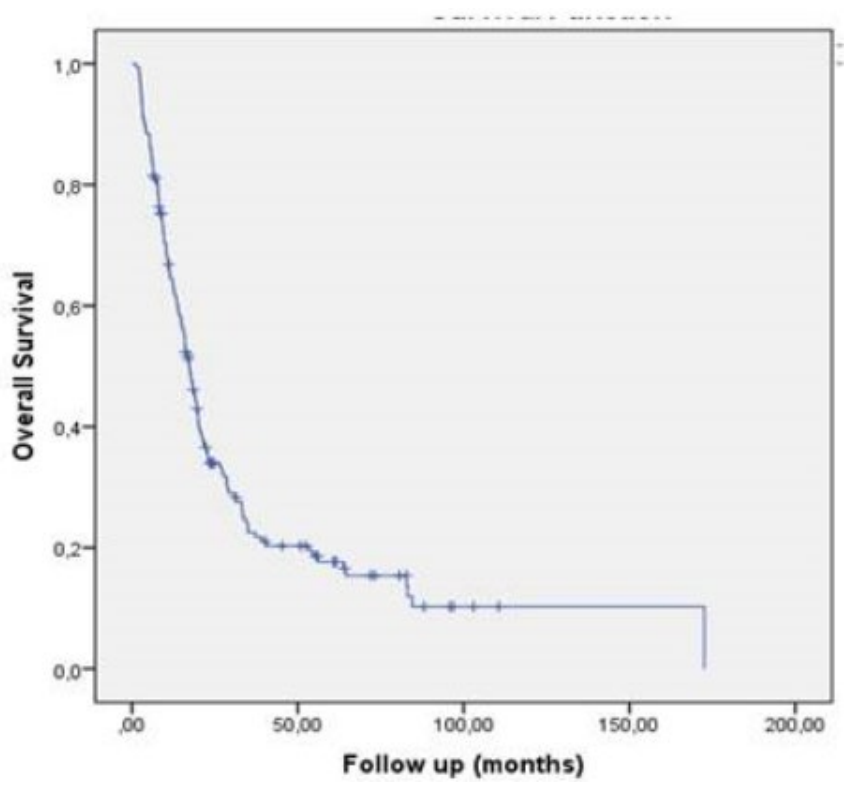

Figure 1. Overall survival curve

Table 3. Multivariate analysis results for overall survival

\begin{tabular}{|c|c|c|c|c|}
\hline \multirow{2}{*}{\multicolumn{2}{|c|}{ Variances }} & \multicolumn{3}{|c|}{ Overall $(n=157)$} \\
\hline & & HR & $95 \% \mathrm{Cl}$ & p value \\
\hline \multicolumn{5}{|l|}{ Age } \\
\hline & $<65$ & 1 & $1.046-2.330$ & $0.029 *$ \\
\hline & $\geq 65$ & 1.561 & & \\
\hline \multicolumn{5}{|l|}{ KPS } \\
\hline & $\geq 80$ & 1 & $0.990-2.235$ & 0.056 \\
\hline & $<80$ & 1.487 & & \\
\hline \multicolumn{5}{|c|}{ Type and extent of surgery } \\
\hline & Total & 1 & $1.122-2.476$ & $0.011 *$ \\
\hline & Subtotal/Biopsy & 1.667 & & \\
\hline \multicolumn{5}{|c|}{ Adjuvant CT } \\
\hline & Yes & 1 & $2.754-7.518$ & $<0.001 *$ \\
\hline & None & 4.550 & & \\
\hline \multicolumn{5}{|c|}{ RT fraction } \\
\hline & Conventional & 1 & $0.945-2.664$ & 0.081 \\
\hline & Hypofractionation & 1.587 & & \\
\hline \multicolumn{5}{|c|}{ Body mass index $\left(\mathrm{kg} / \mathrm{m}^{2}\right)$} \\
\hline & $<30$ & 1 & $0.868-1.901$ & 0.211 \\
\hline & $\geq 30$ & 1.284 & & \\
\hline \multicolumn{5}{|c|}{ Diabetes } \\
\hline & Nondiabetic & 1 & $0.662-1.886$ & 0.676 \\
\hline & Diabetic & 1.118 & & \\
\hline \multicolumn{5}{|c|}{ Pathology } \\
\hline & Grad 3 & 1 & $1.522-4.372$ & $<0.001^{*}$ \\
\hline & Grad 4 & 2.579 & & \\
\hline
\end{tabular}

KPS: Karnofsky Performance Status, CT: Chemotherapy, RT: Radiotherapy

months $(\mathrm{p}=0.017)$ (Figure 2). It could not be shown statistically significant relationship between $\mathrm{BMI}$ and OS.

\section{DISCUSSION}

Diabetes is a metabolic condition that increases the risk of many types of cancer [6]. Many studies have evaluated the relationship between cancer types and DM and BMI. This is not clear in gliomas. Pearson-stuttard et al. showed that alone DM contributes to $2.1 \%$ and high BMI contributes to 


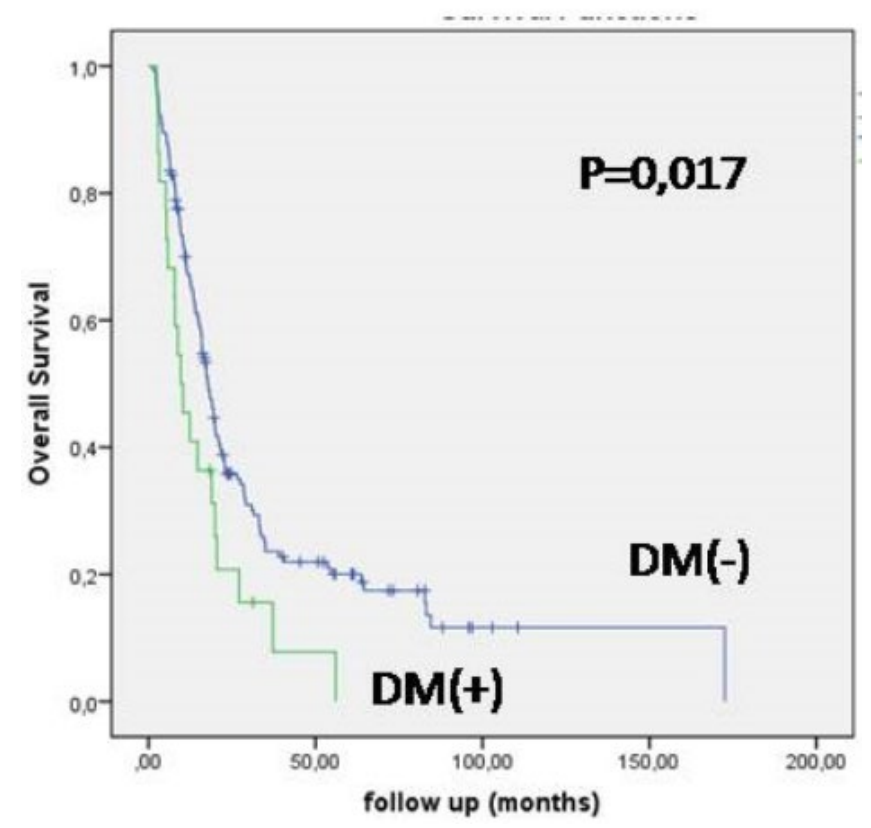

Figure 2. Overall survival curve in patients with and without diabetes in malignant glioma patients

$3.9 \%$ of all cancer cases in 2012 [10]. As obesity and DM continue to increase all over the world, it is predicted that there will be an increase in cancer mortality and incidence in the coming period. In the case-control study conducted by Barami et al., $15.7 \%$ diabetes and $27.7 \%$ obesity were observed in the glioma patient group, while this ratio was $16.8 \%$ and $32.1 \%$, respectively in the control group. There was no relationship between DM and obesity and GBM risk. However, when the relationship between DM and survival was evaluated, it was associated with worse survival in univariate analyzes, but could not be demonstrated in multivariate analyzes [9]. In the metaanalysis performed by Tong et al., no increase was observed in the risk of brain tumors in diabetic and nondiabetic patients [16]. In our study, although the risk between glioma patients and diabetes and obesity was not examined, pre-existing DM has been shown to negatively affect survival in malignant glioma patients. With all these data, it can be said that diabetes has prognostic value, not predisposing.

It has been stated that hyperglycemia is a poor prognostic factor on survival in metaanalysis performed on glioblastoma [17]. Many mechanisms of action of hyperglycemia are emphasized. The level of insulin rises due to acquired insulin resistance. Insulin resistance, increase of various cytokines, increase of insulin - like growth factor-1 (IGF-1), increase of adipokine balance play a role in cancer development [18]. When Derr et al. classified glioblastoma patients according to their blood glucose levels in their study, they found 14.5 months of survival in patients with glucose $<94 \mathrm{mg} / \mathrm{dl}$ and 9.1 months in patients with $>137$ $\mathrm{mg} / \mathrm{dl}(\mathrm{p}=0.041)[19]$.

The increase in obesity causes comorbidities such as cardiovascular disease, DM, cancer [13]. When the relationship between survival and BMI is examined, there are contradictions in the literature. Patharaju et al. showed that the increase in survival occurred when BMI was elevated [20]. However, Chambless et al. showed that DM and high $\mathrm{BMI}$ in high-grade gliomas are independent risk factors for poor results in a retrospective study on 171 patients [3]. These results are contradict with Jones et al. study with 1259 patients. In this study, no relationship was found between BMI and survival [12]. Similarly, in a prospective cohort study for brain tumors, could no relationship was found between obesity and glioma risk [21]. In our study, could no relation was found between BMI and survival. This may be due to the fact that weight and height data were evaluated at the first examination before radiotherapy. Patients may also have experienced weight change due to steroid use before and after the operation.

The limitation of our study was that it was retrospective. HbA1c levels and MGMT status of patients could not be determined before treatment due to the retrospective nature. Clear information on hyperglycemic control adequacy could not be obtained.

\section{CONCLUSION}

As a result, diabetes is a poor prognostic factor for the survival of malignant glioma patients. It is important to control diabetes and related conditions. In the future, prospective studies should be conducted to investigate the relationship and mechanism of action between both DM and high BMI and the risk and mortality of malignant glioma.

\section{DECLARATION OF CONFLICT OF INTEREST}

The authors received no financial support for the research and/or authorship of this article. There is no conflict of interest.

\section{REFERENCES}

1. Gondi V, Vogelbaum MA, Grimm S, Mehta MP Jr: Central Nervous System Tumors. Halperin EC, Wazer DE, Perez CA, Brady LW (eds). Principles and Practice of Radiation Oncology, 7th ed. Philadelphia: Wolters Kluwer; 2019: 799-837. 
2. Stupp R, Hegi ME, Mason WP, et al. Effects of radiotherapy with concomitant and adjuvant temozolamide versus radiotherapy alone on survival in glioblastoma in a randomized phase III study: 5-year analysis of the EORTC-NCIC trial. Lancet Oncology 2009; 10: 459-66. (doi: 10.1016/S1470-2045(09)70025-7).

3. Chambless LB, Parker SL, Hassam-Malani L, McGirt MJ, Thompson RC. Type 2 diabetes mellitus and obesity are independent risk factors for poor outcome in patients with high grade glioma. J Neurooncol 2012; 106: 383-9. (doi: 10.1007/s11060-011-0676-4).

4. He ZQ, Ke C, Al-Nahari F, et al. Low preoperative prognostic nutrional index predicts poor survival in patients with newly diagnosed high-grade gliomas. J Neurooncol 2017; 132: 239-47. (doi: 10.1007/s11060016-2361-0).

5. Trestini I, Carbognin L, Bonaiuto C, Tortora G, Bria E. The obesity paradox in cancer: clinical insights and perspectives. Eat Weight Disord 2018; 23: 185-93. (doi: 10.1007/s40519-018-0489-y).

6. Alarcon S, Niechi I, Toledo F, Sobrevia L, Quezada C. Glioma progression in diabesity. Mol Aspect Med 2019; 66: 62-70. (doi: 10.1016/j.mam.2019.02.002).

7. Park Y, Colditz GA. Diabetes and adiposity: a heavy load for cancer. Lancet Diabetes Endocrinol 2017; 6: 82-3. (doi: 10.1016/S2213-8587(17)30396-0).

8. Saeedi P, Petersohn I, Salpea P, et al. Global and regional diabetes prevalence estimates for 2019 and projections for 2030 and 2045: Results from the International Diabetes Federation Diabetes Atlas, 9th edition. Diabetes Res Clin Pract 2019; 157: 107843. (doi: 10.1016/j.diabres.2019.107843).

9. Barami K, Lyon L, Conell C. Type 2 diabetes mellitus and glioblastoma multiforme-assessing risk and survival: Results of a large retrospective study and systematic review of the literature. World Neurosurg 2017; 106: 3007. (doi: 10.1016/j.wneu.2017.06.164).

10. Pearson-Stuttard J, Zhou B, Kontis V, Bentham J, Gunter MJ, Ezzati M. Worldwide burden of cancer attributable to diabetes and high body-mass index: a comparative risk assessment. Lancet Diabetes Endocrinol 2018; 6: 95-104. (doi: 10.1016/S2213-8587(17)30366-2).
11. Chooi YC, Ding C, Magkos F. The epidemiology of obesity. Metabolism 2019; 92: 6-10. (doi: 10.1016/j.metabol.2018.09.005).

12. Jones LW, Ali-Osman F, Lipp E, et al. Association between body mass index and mortality in patients with glioblastoma multiforme. Cancer Causes Control 2010; 21: 2195-201. (doi: 10.1007/s10552-010-9639-x).

13. Berger NA. Obesity and cancer pathogenesis. Ann N Y Acad Sci 2014; 1311: 57-76. (doi: 10.1111/nyas.12416).

14. Huang X, Shu C, Chen L, Yao B. Impact of sex, body mass index and initial pathologic diagnosis age on the incidence and prognosis of different types of cancer. Oncol Rep 2018; 40: 1359-69. (doi: 10.3892/or.2018.6529).

15. Wang Y, Sun Y, Tang J, Zhou W, et al. Does diabetes decrease the risk of glioma? A systematic review and meta-analysis of observational studies. Ann Epidemiol 2019; 30: 22-9. (doi: 10.1016/j.annepidem.2018.11.010).

16. Tong JJ, Tao h, Hui OT, Jian C. Diabetes mellitus and risk of brain tumours: A meta-analysis. Exp Ther Med 2012; 4: 877-82. (doi: 10.3892/etm.2012.698).

17. Lu VM, Goyal A, Vaughan LS, McDonald KL. The impact of hyperglycemia on survival in glioblastoma: A systematic review and meta-analysis. Clin Neurol Neurosurg 2018; 170: 165-9. (doi: 10.1016/j.clineuro.2018.05.020).

18. Yıldırım N. Obezite ve kanser. Firat Med J 2018; 23: 61-7. (doi: 10.16990/SOBIDER.4188).

19. Derr RL, Ye X, Islas MU, Desideri S, Saudek CD, Grossman SA. Association between hyperglicemia and survival in patients with newly diagnosed glioblastoma. J Clin Oncol 2009; 27: 1082-6. (doi: 10.1200/JCO.2008.19.1098).

20. Pohharaju M, Mangaleswaran B, Mathavan A, et al. Body mass index as a prognostic marker in glioblastome multiforme: A clinical outcomes. Int J Radiat Oncol Biol Phys 2018; 102: 204-9. (doi: 10.1016/j.ijrobp.2018.05.024).

21. Wiedmann MKH, Brunborg C, Di leva A, et al. Overweight, obesity and height as risk factors for menenjioma, glioma, pituitary adenoma and nevre sheath tumor: a large population-based prospective cohort study. Acta Oncol 2017; 56: 1302-9. (doi: 10.1080/0284186X.2017.1330554). 